кандидат історичних наук, доцент кафедри історії Украӥни Дрогобищького державного педагогічного університету імені Івана Франка (Україна, Дрогобич) ryslana_popp@ukr.net

\title{
ІСТОРИЧНИЙ ФАКУЛЬТЕТ ДРОГОБИЦЬКОГО ДЕРЖАВНОГО ПЕДАГОГІЧНОГО УНІВЕРСИТЕТУ ІМЕНІ ІВАНА ФРАНКА В ПЕРШІ ПОВОСННІ РОКИ (1944 - 1953)
}

\begin{abstract}
У статті показано організачію та діяльність історичного факультету Дрогобицького державного педагогічного університету імені Івана Франка в 40-і та на початку 50-х рр. ХХ ст. Характеризується студентський та викладацький склад факультету, зміст навчання і виховання молоді, деякі аспекти тодішнього повсякдення. Простежується вплив суспільно-політичної ситуації у регіоні на роботу вищого навчального закладу та його підрозділу.
\end{abstract}

Ключові слова: Дрогобицький учительський інститут, педагогічний інститут, історичний факультет, викладачі, студенти.

Ruslana POPP,

PhD (History), Associate Professor of Ukraine's History Department, Drohobych Ivan Franko State Pedagogical University (Ukraine,Drohobych) ryslana_popp@ukr.net

\section{THE HISTORICAL FACULTY OF DROHOBYCH STATE PEDAGOGICAL UNIVERSITY DURING THE FIRST POSTWAR YEARS (1944 - 1953)}

The article is devoted to the issue of organization and activity of the faculty of history of Ivan Franko Drohobych State Pedagogical University in the 1940s - first half of the 1950s. Today in Ukraine an educational reform is being carried out. Historical reflections and objective analysis of the past will help to identify important aspects of development not only of separate branches of education and science, but also the functioning of separate educational institutions, and to take them into account in modern realities.

The main idea of the article is to show the organization and activity of the historic faculty of Drohobych Teachers' Institute (as the present-day Drohobych University was called) in the 1940s and early 1950s; to describe the student and teacher staff of the faculty, the content of training and education of youth, some aspects of the then everyday life; to trace the influence of the socio-political situation in the region on the work of a higher educational establishment and its subdivisions.

The formation in Drohobych of a higher pedagogical institution was associated with the processes of Sovietization on the western lands of Ukraine. Higher education, especially pedagogical, was an important ideological tool for the Stalinist system, a source of the formation of a new Soviet intelligentsia. The first post-occupational entree plan for students at the Faculty of History was 60 students. It went through difficulties and scored two-thirds of the plan. A small number of secondary school graduates was the reason for the shortage. The youth had 6-7 years of school education after the German occupation. In 1952, the faculty enrolled already 50 students. In the postwar years, Ukrainians prevailed among the students. However, the share of local youth was insignificant due to political reasons. From the mid-40's to the mid-50's of the twentieth century only 830 teachers-historians were trained at the faculty.

In 1946, the staff of the Department of History, which provided teaching at the Faculty of History, comprised 2 teachers. In the first post-war years P. Kozik, V. Tychyna, V. Tryhub, O. Zaichenko, I. Kosharnyi, P. Marunya, O. Dybenko, I. Lisinchuk worked at the department. At the beginning of the work, none of the members of the department staff had a degree or an academic rank. In 1950 P. Kozik defended his PhD thesis.

Initially, in the content of education the communist party ideology was prevalent, which was implemented into curricula, programs, and manuals. The students were subjected to ideological treatment, the selection was held in respect of political confidence.

The conditions of life and work in the first postwar years were complicated. The situation slowly improved. 
The Historical Faculty had began its work in 1940 and renewed its activities after the German occupation. During the first postwar years, students and departments of the faculty were gradually formed and the everyday life became settled. The communist party ideology of education and training, neglect of national-spiritual traditions, repressive measures of the power regarding students and teachers negatively affected the training of teachers.

Key words: Drohobych Teachers'Institute, Pedagogical Institute, faculty of history, teachers, students.

Руслана ПОПП, кандидат исторических наук, дочент кафедры истории Украины Дрогобычского государственного педагогического университета имени Ивана Франко (Украина, Дрогобыч) ryslana_popp@ukr.net

\section{ИСТОРИЧЕСКИЙ ФАКУЛЬТЕТ ДРОГОБЫЧСКОГО ГОСУДАРСТВЕННОГО УНИВЕРСИТЕТА ИМЕНИ ИВАНА ФРАНКА В ПЕРВЫЕ ПОСЛЕВОЕННЫЕ ГОДЫ}

(1944 - 1953)

В статье показано организачию и деятельность исторического факультета Дрогобычского государственного педагогического университета имени Ивана Франко в 40-е и в начале 50-х гг. Характеризуется студенческий и преподавательский состав факультета, содержание обучения и воспитания молодежи, некоторые аспекты повседневности того времени. Прослеживается влияние общественно-политической ситуации в регионе на работу высшего учебного заведения и его подразделения.

Ключевые слова: Дрогобычский учительский институт, педагогический институт, исторический факультет, преподаватели, студентыл.

Постановка проблеми. Вивчення освітніх процесів у регіональному розрізі, за певний історичних умов, допоможе відтворити цілісну картину історії краю та окремих його локацій. Сьогодні в Україні відбувається освітня реформа. Історичні рефлексії та об'єктивний аналіз минулого допоможуть визначити важливі аспекти розвитку як окремих галузей освіти та науки, так і функціонування окремих навчальних закладів, врахувати це в сучасних реаліях.

Аналіз досліджень. Діяльність Дрогобицького державного університету імені Івана Франка від заснування до сучасності висвітлені у двох виданнях, присвячених його історії (Дрогобицький ДПУ, 2001; Дрогобицький ДПУ, 2010). Біографічні відомості про викладачів вищого навчального закладу зібрані у книзі «Історія Дрогобицького педагогічного університету імені Івана Франка в іменах» (Історія, 2005). Окремі періоди історії університету розкриті у наукових розвідках М. Галіва (Галів, 2011), Р. Попп (Попп, 2009; 2011). Основні етапи розвитку історичного факультету показано у ювілейному виданні «Історичний факультет Франкового університету в Дрогобичі 1940 - 2007» за редакцією Л. Тимошенка (Історичний факультет, 2007).

Мета статті - висвітлити організацію та діяльність історичного факультету теперішнього Дрогобицького державного педагогічного університету імені Івана Франка в 40-і - на поч. 50-х рр. ХХ ст.

Виклад основного матеріалу. Дрогобицький учительський інститут розпочав роботу ще до війни. Постанова політбюро ЦК КП(б) та Раднаркому УРСР про його створення була видана 15 квітня (Дрогобицький державний педагогічний університет ім. Івана Франка, 2001: 20). Першого вересня 1940 р. відбулося відкриття вищого навчального закладу у складі історичного, мовно-літературного та фізико-математичного факультетів 3 денною, вечірньою та заочною формами навчання (Галів, 2011: 64). Утворення в регіоні вищого педагогічного навчального було пов'язане 3 радянізаційними процесами на західних землях України. Вища освіта, особливо педагогічна, для сталінської системи була важливим ідеологічним засобом, джерелом формуванням нової радянської інтелігенції.

Про довоєнний період історії університету та його історичного факультету збереглося мало документів. М. Галіву вдалося з'ясувати, що першим деканом історичного факультету був Ю. Новак, викладач історії народів СРСР (Галів, 2011: 64). Історію стародавнього світу викладав П. Ко- 
зік, який того року закінчив Київський державний університет імені Т. Г. Шевченка (Історія Дрогобицького педагогічного університету імені Івана Франка в іменах, 2005: 80-81). Щодо кількості студентів, то у січні 1941 р. на факультеті навчалися 80 осіб (Галів, 2011: 64), навчальний процес розгортався на засадах радянської вищої школи. Студентська молодь почала вивчати марксистсько-ленінську теорію, політичну економію, історію СРСР та УРСР, історію літератури народів Радянського Союзу (Галів, 2011: 65).

Відновив свою роботу історичний факультет Дрогобицького учительського інституту вже після вигнання німецьких окупантів, коли в місті знову утверджується радянська система. Сталінський режим намагався якнайшвидше інтегрувати західноукраїнський регіон до складу Радянського Союзу, уніфікувати усі культурно-освітні процеси, подолати спротив ОУН і УПА та підтримку українського визвольного руху місцевим населенням. Для налагодження роботи навчального закладу були прийняті як урядові постанови, так і численні розпорядження, доповідні записки місцевих партійних та радянських органів влади (Попп, 2009: 121).

Перший після окупації план набору студентів на історичний факультет становив 60 студентів. Він пройшов із труднощами, набрали дві третини визначеного плану. Причиною недобору була мала кількість випускників середніх шкіл - після німецької окупації молодь мала 6-7-річну освіту (Дрогобицький державний педагогічний університет ім. Івана Франка, 2001: 35). У наступні роки план набору істориків на денну форму навчання зменшувався до 30, 25 осіб (ДАЛО. Ф. Р-2018. Оп.1. Спр.10. Арк. 31; ДАЛО. Ф. Р-2018. Оп. 2. Спр. 10. Арк. 89). У 1951 р. на 25 місць було подано 132 заяви, у 1952 р. зарахували вже 50 осіб (Історичний факультет, 2007: 9)

Для підготовки вступників у Дрогобицькому учительському інституті створювалися підготовчі відділи, курси з відривом та без відриву від виробництва, продовжувалися терміни подачі документів, оголошувалися додаткові набори. Щоб за будь-яких умов виконати державні плани набору до учительських інститутів приймали навіть осіб із незакінченою середньою освітою. На початку 1945/46 навчального року з Дрогобицького учительського інституту через відсутність повної середньої освіти був відрахований 21 студент (Попп, 2009: 122).

Кількість студентів на історичному, як і на інших факультетах у перші повоєнні роки постійно змінювалася. Збільшувалася через додаткові набори, переведення з інших навчальних закладів, протягом року зараховувалися демобілізовані з армії, зменшувалася через відрахування. Відраховували за пропуски занять, через проблеми зі здоров'ям, переведення до інших навчальних закладів, зміну місця проживання, адже в цей період відбувалися значні переміщення, масові депортації населення. На середину червня 1946 р. на факультеті навчалися 74 студенти денної та 43 заочної форми навчання (ДАЛО. Ф. Р-2018. Оп. 3.Спр. 83. Арк. 18). На початку вересня 1952 p. на стаціонарі було 80 студентів істориків (ДАЛО. Ф.Р-2018. Оп.1. Спр. 83. Арк. 14-15). У 1952 р. Дрогобицький учительський інститут був реорганізований у педагогічний інститут. Учительські інститути здійснювали підготовку вчителів 5-7-х класів і навчання тривало два роки, а педагогічні інститути - 8-10-х класів протягом чотирьох років. 3 1952/53 навчального року підготовка вчителів історії велася вже на історико-філологічному факультеті. В 1956 р. прийом студентів на історичну спеціальність припинився. Студентів з Дрогобича було переведено на навчання до Львова (Історичний факультет, 2007: 9).

Перший випуск випускників історичного факультету в Дрогобичі відбувся у лютому 1947 р., тоді закінчили навчання на факультеті 33 особи (ДАЛО. Ф. Р-2018. Оп. 1. Спр. 15. Арк. 33). Цікаво, що у звіті голови екзаменаційної комісії зазначалося, що під час держіспитів в інституті були «спроби користуватися шпаргалками, особливо на історичному факультеті» (ДАЛО. Ф. Р-2018. Оп.1. Спр. 10. Арк. 1). У червні 1947 р. відбувся ще один випуск істориків. Тоді один студент був не допущений до іспитів через неуспішність, чотири не склали його, успішно захистилися 35 студентів стаціонарної форми навчання і один заочної, п’ять отримали диплом з відзнакою (ДАЛО. Ф. Р-2018. Оп. 14. Спр. 14. Арк. 6). На державні екзамени виносилися такі дисципліни: основи марксизму-ленінізму, педагогіка, історія СРСР, історія стародавнього світу і середніх віків. Усього 3 середини 40-х і до середини 50-х років ХХ ст. на факультеті було підготовлено 830 вчителів-істориків (Історичний факультет, 2007: 9). 
У повоєнні роки серед студентів переважали українці. Утім частка місцевої молоді була незначною. На історичному факультеті навесні 1947 р. серед 43 студентів було: 18 хлопців, 25 дівчат, 11 місцевих (ДАЛО. Ф. Р-2018. Оп.1. Спр. 15. Арк. 56). Карні органи пильно стежили за контингентом вступників та за студентами учительського інституту. У Директиві управління у справах вищої школи від 10 жовтня 1946 р., під грифом «Таємно», вимагалося від керівництва Дрогобицького учительського інституту прискорити подання відомостей «про партійний, національний, віковий склад усіх студентів» (Попп, 2009: 124). Постійні перевірки і чистки виявляли «класово ворожі елементи», що, як правило, були дітьми заможних селян, священиків, членами ОУН і УПА, або мали родинні зв'язки з українськими повстанцями. Визначальною була політична благонадійність. У звіті про державні іспити у Дрогобицькому учительському інституті (1948) зазначалося, що «значно слабший політичний розвиток студентів, які виросли і закінчили середні школи в умовах Західної України» (ДАЛО. Ф.Р-2018. Оп. 15. Спр. 15. Арк. 1)

У кінці першого семестру 1945 р. в учительському інституті був лише один викладач історії (ДАЛО. Ф. П-5001. Оп. 6. Спр. 213. Арк. 20). У 1946 р. в штаті кафедри історії, яка забезпечувала викладання на історичному факультеті, було два викладачі. Повернувся на роботу до Дрогобича П. Козік, з 1946 р. на кафедрі історії розпочинає працювати випускник Київського університету імені Т. Г. Шевченка, ветеран війни В. Тичина (Історія, 2005: 81, 183). У повоєнні роки членами кафедри були також: В. Тригуб (з серпня 1946 р. до травня 1948 р. був заступником директора 3 навчальної і наукової роботи), О. Заїченко, І. Кошарний, П. Маруня, О. Дибенко, І. Лісінчук (ДАЛО. Ф. Р-2018. Оп. 14. Спр. 14. Арк. 3,4; ЦДАВО. Ф. 12. Оп. 31. Спр. 1154. Арк. 20; ЦДАВО. Ф. 166. Оп. 15. Спр. 978. Арк. 35).

До 1949 р. кафедру історії очолював Павло Козік. 31949 до 1956 рр. - Іван Кошарний (Історія Дрогобицького педагогічного університету імені Івана Франка в іменах, 2005: 81, 92). На вченій раді інституту в серпні 1948 р. зазначалося, що «кафедра історії справилася зі своєю роботою, але поряд мала і недоліки. Члени кафедри історії показували з себе людей високомірних, а історію ставили понад усе» (ДАЛО. Ф. Р-2018. Оп. 17. Спр. 17. Арк. 49). Насправді, це дуже дивний «недолік». На початках роботи жодний із членів кафедри не мав наукового ступеня чи вченого звання. У 1950 р. П. Козік захистив кандидатську дисертацію «Відбудова та розвиток господарства та культурного життя Дрогобицької області після вигнання німецько-фашистських загарбників». У 1951 р. кандидатську дисертацію на тему «Селянське повстання на Стародубщині у 40-70-х роках XVIII ст.», захистив Петро Маруня, у 1952 р. роботу «Культурне будівництво в Дрогобицькій області за роки Радянської влади. 1939 - 1950-і рр.» - Іван Кошарний (Історія, 2005: 92). Теми дисертацій яскраво демонструють тодішній заідеологізований напрям наукових досліджень.

Керівний склад вищого навчального закладу, декани факультетів входили до номенклатурних посад, тому після ретельного вивчення особових справ затверджувалися на рівні міністерства (ДАЛО. Ф. Р-2018. Оп. 3. Спр. 3. Арк. 92). У 1945/46 навчальному році на чотирьох відділеннях інституту не було жодного затвердженого декана (ЦДАВО. Ф. 166. Оп. 16. Спр. 180. Арк. 11). У березні 1947 р. Міністерство освіти УРСР зобов'язувало директора інституту І. Копійка вдруге надіслати «спецпоштою» особові справи деканів факультетів (ДАЛО. Ф. Р-2018. Оп. 3. Спр. 3. Арк. 72). Деканом історичного факультету у повоєнні роки був Владислав Тичина (1947 - 1949), у 1949 - 1950 рр. цю посаду обіймав Павло Козік (завідувач фізико-математичного та історичного відділів), деканом історико-філологічного факультету у 1952 р. був філолог, викладач російської мови Олександр Тілло (Історичний факультет, 2007: 9).

Партійно-комуністична ідеологія насаджувалася передовсім через зміст освіти, який реалізовувався у навчальних планах, програмах, підручниках. Вони уніфікувалися, розроблялися під постійним наглядом партійних органів. Навчальний план історичного факультету у перші повоєнні роки передбачав вивчення 17 нормативних дисциплін. На вивчення історії стародавнього світу відводилося 198 год., історії середніх віків - 216 год., історії нового часу - 170 год., історії СРСР 370 год., історії України - 108 год. та методики викладання історії - 60 год. (Історичний факультет, 2007: 9). Як бачимо, на вивчення історії СРСР, відводилося в 3,5 раза годин більше ніж України. Крім історичних дисциплін, історики вивчали, українську, російську літературу, правопис, педагогіку. Важлива роль відводилася суспільним наукам: основам марксизму-ленінізму, Конституції 
СРСР (ДАЛО. Ф. Р-2018. Оп. 1. Спр. 15. Арк. 31). Останні мали винятково ідеологічне спрямування, виховували у майбутніх вчителів комуністичний світогляд, «радянський патріотизм». Такі ж погляди пізніше вони «мали прищеплювати» своїм учням. Під час проходження педагогічної практики студенти-історики проводили уроки з історії, Конституції СРСР і УРСР. До початку 1947 р. обов'язковою була військова підготовка (ДАЛО. Ф. Р-2018. Оп. 1. Спр. 65. Арк. 15). 3 початку 1950 р. академічна година тривала 45-50 хвилин, перерви між заняттями становили 1015 хвилин, а кількість дисциплін, які вивчали студенти, зокрема, історики, не мала перевищувати трьох на день (ДАЛО. Ф. Р-2018. Оп. 1. Спр. 1. Арк. 27).

У звіті Дрогобицького учительського інституту за 1947/48 навчальний рік відзначалося, що робочі програми кафедри історії «будувалися так, щоб забезпечити дієву боротьбу проти рецидивів буржуазної ідеології, ідеології українського буржуазного націоналізму на історичному фронті» (ДАЛО. Ф. Р-2018. Оп. 1. Спр. 5. Арк. 27). У період повоєнних ідеологічних кампаній, а особливо «боротьби з історичної школою Грушевського та його учнями», «безрідним космополітизмом», замість об'єктивної, справжньої історії підсовували «москвоцентричну», сфальсифіковану історію України (Дашкевич, 1996: 69). Стенограми окремих лекцій з історії, марксизму-ленінізму мали відсилалися у десятиденний термін на перевірку в Управління Міністерства вищої освіти, їх відвідували інспектори міністерства та Управління вищої школи при раді Міністрів УРСР і навіть представник ЦК КП(б)У та Дрогобицького міського комітету партії. В 1947/48 навчальному році таких перевірок, як зазначається у звіті, було понад 20 (ДАЛО. Ф. Р-2018. Оп. 1. Спр. 5. Арк. 16). Стан викладання історії України в Дрогобицькому учительському інституті за дорученням Управління вищої школи Міністерства освіти УРСР, перевіряла кафедра історії Львівського педагогічного інституту (ДАЛО. Ф. Р-2018. Оп. 3. Спр. 3. Арк 92.). 18 грудня 1947 р. це питання заслуховувалося на колегії Міністерства (ДАЛО. Ф. Р-2018. Оп. 3. Спр. 3. Арк. 258). Щоб показати всю абсурдність переслідувань та звинувачень щодо викладачів, наведемо лише один приклад. На відкритих партійних зборах партійної організації інституту в квітні 1949 р. викладачку історії Г. Лісніченко, критикували за те, що під час лекції на тему «Вітчизняна війна 1812 р.» вона нічого не згадала про Велику Вітчизняну війну. Найбільше обурювало критиканів такий факт: незважаючи на те, що це «явна хиба», викладачка і надалі відстоювала свою правоту. За «відрив від сучасності» були розкритиковані і лекції П. Козіка (ДАЛО. Ф. Р-2018. Оп. 3. Спр. 3. Арк. 22). У підсумку партійні збори постановили: «Рішуче боротись і до кінця викривати будь-які спроби низькопоклонства перед іноземною буржуазною культурою Західної Європи, українським буржуазним націоналізмом, якими формами вони не прикривались» (ДАЛО. Ф. Р-2018. Оп. 3. Спр. 3. Арк. 26)». За ідеологічними нападками, як правило, йшли організаційні висновки. У квітні 1952 р. за прояви «буржуазного націоналізму» був звільнений П. Козік ( Попп, 2009: 128).

У кожному вищому навчальному закладі важлива роль надавалася кафедрам марксизму-ленінізму, створювалися партійні й комсомольські організації. Однак у матеріалах перевірки учительського інституту, яку проводило Управління у справах вищої школи при Раді Міністрів УРСР (1947) наголошувалося, що «кафедра основ марксизму-ленінізму так і не стала провідною в інституті» (ДАЛО. Ф. Р-2018. Оп. 2. Спр. 2. Арк. 116). Ідейно-політичне загартування молоді здійснювалося через лекції, політінформації, семінари, літературу, мистецтво, кіно. Постійними були різноманітні збори, конференції, політінформації. Ідеологічний тиск, примус часто викликали страх, який, своєю чергою, зумовлював замовчування своїх правдивих переконань, але деякі студенти не боялися говорити правду, виступати проти формалізму, фальшивості та тупості. Після загальних зборів студентів та викладачів інституту в грудні 1948 р., студент другого курсу історичного факультету Сивиляк назвав комсомольського активіста Витачака кар'єристом. Відразу про це стало відомо керівництву і було ініційоване «глибше вивчення» цього студента, з'ясувалося, що він не «одобряє колективізацію» (ДАЛО. Ф. Р-2018. Оп. 47. Спр. 48. Арк. 12). Орієнтуватися у справжніх настроях і реакціях молоді на усі зміни, які відбувалися в західних областях України, режиму допомагали не тільки радянські спецслужби, а й активно заохочувалося в усіх колективах практика донощицтва. 3 пізнавальної та пропагандивної метою для студентів організовувалися екскурсії студентів до східних районів України та СРСР. У 1948 р. така екскурсія за 
маршрутом Львів-Київ-Москва була організована для п’ятнадцяти кращих студентів інституту. Серед них було двоє студентів історичного факультету (ДАЛО. Ф. Р-2018. Спр. 18. Арк. 71-72).

У 1945/46 навчальному році навчальне навантаження для викладачів історії мало становити 550 годин, для завідувача кафедри - 420 (ДАЛО. Ф.Р-2018. Оп. 1. Спр. 10. Арк. 15). Крім навчання та викладацької роботи, викладачів і студентів залучали до активної громадської діяльності: читання лекцій на «актуальні політичні» теми для населення області, публікацій у пресі, до участі у виборчих компаніях до радянських органів влади, парадах та інших радянських заходах (ЦДАВО. Ф. 166. Оп. 16. Спр. 180. Арк. 20). «Правильну позицію» потрібно було доводити вступом у до лав комуністичної партії, комсомолу.

Дуже часто заходи ідейно-політичного виховання молоді не давали очікуваного результату. У лютому 1948 p. із 23 студентів першого курсу історичного факультету стаціонарної форми навчання троє були членами КП(б)У і п’ятеро - членами ВЛКСМ, на другому курсі відповідно був один комуніст і шість комсомольців (ДАЛО. Ф. Р-2018. Оп. 16. Спр. 416. Арк. 14). На засіданні вченої ради наголошувалося: «На низькому рівні стоїть зростання комсомольської організації, питання антирелігійної роботи. Студенти прямо заявляють, що до церкви вони ходять, що вступати до комсомолу бояться. І будуть жити як жили» (ДАЛО. Ф. Р-2018. Оп. 47. Спр. 48. Арк. 22-23).

Війна заподіяла надзвичайно великі збитки, а це, зі свого боку, позначилося на повсякденні повоєнного студентства та викладачів. Відразу після війни заняття часто проходили у холодних аудиторіях, звичними були перебої з постачанням електроенергії, бракувало навчального приладдя, підручників, просто алементарного паперу. Наприкінці 1945/46 навчального року у користуванні студентів інституту було сім тисяч книг і журналів, однак навчальної історичної літератури суттєво не вистачало (Попп, 2009: 129). На 1 липня 1951 р. книжковий фонд бібліотеки складав уже 35 тисяч книг (ДАЛО. Ф. Р-2018. Оп. 1. Спр. 65. Арк. 64). Читальний зал бібліотеки, який працював з 11 години ранку до 22 години вечора, часто відвідували студенти-історики (ДАЛО. Ф.Р-2018. Оп. 1. Спр. 83. Арк. 63). Працював також історичний кабінет, в якому була зібрана історична література, схеми, таблиці, карти (ДАЛО. Ф. Р-2018. Оп. 14. Спр. 14. Арк. 1-2.). Відвідування кабінету історії, особливо марксизму-ленінізму студентами ретельно фіксувалося.

У перші повоєнні роки студенти та викладачі отримували картки на продовольчі й промислові товари. У середньому добова норма хліба для студентів інституту становила 500 грамів, стільки ж отримували і заочники, які приїжджали на екзаменаційні сесії, а для викладача - 600 (Попп, 2009: 129). За особливим розпорядженням Управління робітничого і студентського постачання Міністерства освіти УРСР Дрогобицькому учительському інституту на другий квартал 1946 р. було виділено додаткове харчування для студентів (ДАЛО. Ф. Р-2018. Оп. 3. Спр. 3. Арк. 69). Водночас звичними були проблеми із отоварюванням карток і якістю продуктів, які видавали за талонами, або взагалі з їх відсутністю. Особливо не вистачало промислових товарів. Продукти на ринку були надзвичайно дорогі. Ціни на перше жовтня 1946 р. на продовольчому ринку Дрогобича були такими: м'ясо - 310 крб., борошно - 332, хліб житній - 7, пшеничний - 22, десяток яєць - 22 крб. У 1947 р. місячний оклад старшого викладача кафедри історії становив 1200 крб. (Попп, 2009: 130). В 1947 р. була відмінена карткова система, і ситуація поволі почала поліпшувалася.

Дрогобицький учительський мав підсобне господарство, викладачі обробляли городи. Здебільшого молодь сама готувала їжу, привозила 3 продукти з дому. Студенти отримували стипендію, яка залежно від курсу становила 220 - 265 крб. на місяць. Відмінники навчання отримували на 3 \% більші виплати, студенти, з дітьми мали право на отримання грошової допомоги. Надбавки до стипендії мали інваліди, Герої Радянського Союзу і Соціалістичної Праці. Були й іменні стипендії, однак для їх отримання потрібно було мати бездоганні анкетні дані. Вчена рада Дрогобицького учительського інституту рекомендувала сталінським стипендіатом в 1950/51 навчальному році студента 2 курсу історичного факультету Михайла Одінцова, в характеристиці на нього зазначалось: відмінник навчання, член ВКП(б), ветеран війни, заступник голови студпрофкому, активний організатор і учасник агітаційно-пропагандивної та культурно-масової роботи серед населення міст і сіл області (ДАЛО, Ф. Р.2018. Оп. 1. Спр. 6. Арк. 61).

У перші повоєнні роки складними були і житлові умови. У 1945/46 навчальному році житлова площа гуртожитків інституту задовольняла потреби у забезпеченні студентів помешканням на 
65 \%. Не завжди відповідними були і умови проживання в гуртожитках. За «антисанітарний стан і відсутність елементарного там порядку» та незабезпеченість паливом директор інституту Г. Копійко отримав в лютому 1947 р. догану від Міністерства освіти УРСР (ДАЛО. Ф. Р-2018. Оп. 3. Спр. 3. Арк. 36). Бракувало квартир і для працівників інституту. У 1952 р. році інститут мав уже три гуртожитки, де проживали 348 студентів інституту (загалом на початку навчального року було 471) (ДАЛО. Ф. Р-2018. Оп. 1. Спр. 83. Арк. 15). Збільшення чисельності студентів вимагало і розширення навчальних приміщень, через їх нестачу заняття у 1953/54 навчальному році відбувалося у дві зміни. У 1952 р. за інститутом було закріплено 4 будинки на 16 квартир, але потрібно було ще 25 квартир. Деяким розв'язанням проблеми було індивідуальне будівництво житла. Для цього в літку 1947 р. для працівників інституту було виділено державну позику на 20000 крб. (Попп, 2009: 130).

Попри всі колізії і труднощі того часу студенти інституту брали участь у наукових і самодіяльних гуртках. Упродовж кількох років працював історичний гурток. Крім того, що студенти готували референти, доповіді на актуальні з ідологічної точки зору теми, вони збирали матеріали з історії Дрогобича та регіону, отримували навики науково-дослідницької роботи. Популярними серед істориків були драматична студія, хоровий і хореографічний гуртки, а також різноманітні спортивні секції: волейболу, футболу, гімнастики, легкої атлетики, шахів, студенти були активними учасниками різноманітних змагань, естафет, оглядів художньої самодіяльності. Організовувалися літературні свята, вечори відпочинку з танцями, студенти відвідували театральні вистави, кіно (Попп, 2011: 100-101). Студентське дозвілля за змістом мало сприяти політико-ідеологічному вихованню, тому більшість заходів здійснювалися під керівництвом і під контролем комсомольських організацій інституту та міста.

Висновки. Заснування у Дрогобичі учительського інституту було пов’язане з радянізаційними процесами на західних землях України. Вища освіта, особливо педагогічна, для сталінської системи була важливим ідеологічним засобом, джерелом формуванням радянської інтелігенції. Історичний факультет розпочав свою роботу у 1940 р. і поновив діяльність вже після німецької окупації. У перші повоєнні роки поступово формується студентський та викладацький колективи факультету, налагоджується повсякдення. Партійно-комуністична заідеологізованість навчання та виховання, нехтування національно-духовними традиціями, репресивні заходи влади щодо студентів і викладачів негативно позначалися на підготовці педагогів-істориків.

Перспективним напрямом вивчення проблеми може бути дослідження діяльності історичного факультету з часу його відновлення у 1992 р.

\section{СПИСОК ВИКОРИСТАНИХ ДЖЕРЕЛ І ЛІТЕРАТУРИ}

Галів, 2011 - Галів М. Д. Дрогобицький державний учительський інститут: перший рік роботи (1940 - 1941) // Молодь і ринок: Щомісячний науково-педагогічний журнал. 2011. № 2 (73). С. 62-67.

ДАЛО - Державний архів Львівської області.

Дашкевич, 1996 - Дашкевич Я. Боротьба з Грушевським та його львівською школою за радянських часів // Український історик. 1996. № 1-4 (128-131). Вип. XXXIII. С. 88-142.

Дрогобицький ДПУ, 2001 - Дрогобицький державний педагогічний університет ім. Івана Франка, за редакцією Валерія Скотного, Юрія Кишакевича та ін. Дрогобич; Львів, 2001. 328 с.

Дрогобицький ДПУ, 2010 - Дрогобицький державний педагогічний університет ім. Івана Франка [2-е видання], за редакцією Валерія Скотного, Юрія Кишакевича та ін. Дрогобич, 2010. 308 с.

Історичний факультет, 2017 - Історичний факультет Франкового університету в Дрогобичі (1940 - 2007): ювілейна книга до 15-річчя відновлення факультету / Ред. кол. Л. Тимошенко (голов. ред.), В. Здоровенко, Тимошенко, В. Футала, С. Щудло / Упорядники А. Петрик, 3. Соболь, Б. Лазорак. Дрогобич: Коло, 2007. $110 \mathrm{c}$.

Історія, 2005 - Історія Дрогобицького педагогічного університету імені Івана Франка в іменах, за редакцією, Юрія Кишакевича. Дрогобич, 2005. 224 с.

Попп, 2009 - Попп Р. П. Педагогічний університет імені Івана Франка у перші повоєнні роки (1944 1953) // Проблеми гуманітарних наук. Наукові записки ДДПУ імені Івана Франка. Історія. 2009. Випуск двадцять четвертий. С. 120-135.

Попп, 2011 - Попп Р. П. Формування інтелігенції західних областей України в перші повоєнні роки (на матеріалах Дрогобицького учительського інституту) // Інтелігенція і влада. 2011. Вип. 23. С. 94-104. 
ЦДАВО - Центральний державний архів вищих органів влади України.

\section{REFERENCES}

Haliv, 2011 - Haliv M. D. Drohobytskyi derzhavnyi uchytelskyi instytut: pershyi rik roboty $(1940-1941)$ [Drohobych State Teachers' Institute: first year of work (1940 -1941)] // Molod i rynok: Shchomisiachnyi naukovopedahohichnyi zhurnal. 2011. №2 (73). S. 62-67. [in Ukrainian].

DALO - Derzhavnyi arkhiv Lvivskoi oblasti [State Archive of Lviv Region]. [in Ukrainian].

Dashkevych, 1996 - Dashkevych Ya. Borotba z Hrushevskym ta yoho lvivskoiu shkoloiu za radianskykh chasiv [Fight against Hrushevskyj and his Lviv school in Soviet times] // Ukrainskyi istoryk. 1996. № 1-4 (128-131). Vyp. XXXIII. S. 88-142. [in Ukrainian].

Drohobytskyi DDPU, 2001 - Drohobytskyi derzhavnyi pedahohichnyi universytet im. Ivana Franka [Drogobych State Pedagogical University named after Ivan Franko], za redaktsiieiu Valeriia Skotnoho, Yuriia Kyshakevycha ta in. Drohobych; Lviv, 2001. 328 s. [in Ukrainian].

Drohobytskyi DDPU, 2010 - Drohobytskyi derzhavnyi pedahohichnyi universytet im. Ivana Franka [Drogobych State Pedagogical University named after Ivan Franko] [2-e vydannia], za redaktsiieiu Valeriia Skotnoho, Yuriia Kyshakevycha ta in. Drohobych, 2010. 308 s. [in Ukrainian].

Istorychnyi fakultet, 2017 - Istorychnyi fakultet Frankovoho universytetu v Drohobychi (1940-2007): yuvileina knyha do 15-richchia vidnovlennia fakultetu / Red. kol. L. Tymoshenko (holov. red.), V. Zdorovenko, Tymoshenko, V. Futala, S. Shchudlo / Uporiadnyky A. Petryk, Z. Sobol, B. Lazorak. Drohobych: Kolo, 2007. 110 s.

Istoriia, 2005 - Istoriia Drohobytskoho pedahohichnoho universytetu imeni Ivana Franka v imenakh [History of the Ivan Franko Drohobych Pedagogical University in names], za redaktsiieiu, Yuriia Kyshakevycha. Drohobych, 2005. 224 s. [in Ukrainian].

Popp, 2009 - Popp R. P. Pedahohichnyi universytet imeni Ivana Franka u pershi povoienni roky (1944 - 1953) [Ivan Franko Pedagogical University during the first post-war years (1944 - 1953)] // Problemy humanitarnykh nauk. Naukovi zapysky DDPU imeni Ivana Franka. Istoriia. 2009. Vypusk dvadtsiat chetvertyi. S. 120-135. [in Ukrainian].

Popp, 2011 - Popp R. P. Formuvannia intelihentsii zakhidnykh oblastei Ukrainy v pershi povoienni roky (na materialakh Drohobytskoho uchytelskoho instytutu) [Formation of the intellectuals of the western regions of Ukraine during the first postwar years (based on the materials of the Drogobych Teachers' Institute)] // Intelihentsiia i vlada. 2011. Vyp. 23. S. 94-104. [in Ukrainian].

TsDAVO. - Tsentralnyi derzhavnyi arkhiv vyshchykh orhaniv vlady Ukrainy [Central state archive of higher authorities of Ukraine]. [in Ukrainian].

Стаття надійшла до редакиї 2.02.2018 р. 